\title{
Professional liability of plastic surgeons in Canada
}

\author{
W Bryan Callaghan MD FRCSC \\ Case Review Committee, Canadian Medical Protective Association, Ottawa, Ontario
}

\begin{abstract}
WB Callaghan. Professional liability of plastic surgeons in Canada. Can J Plast Surg 1997;5(4):230-232. The medicolegal experience of Canadian plastic surgeons from 1980 to 1995 was reviewed. During the most recent six years (1990 to 1995) 331 legal actions were closed, and these files were analyzed by the Education Department at the Canadian Medical Protective Association. Lawsuits arose most frequently from breast surgery (26\%); facial surgery $(21 \%)$ and hand surgery $(19 \%)$ also contributed to lawsuits. Outcomes revealed that cases were often dismissed (64\%) or won if they advanced to trial (9\%); however, $23 \%$ required settlement on behalf of the defendant surgeon, while $4 \%$ were lost at trial. The largest damages awarded were in cases arising from hand surgery. The high cost of defending plastic surgeons is a reflection of frequency rather than severity of cases giving rise to legal actions.
\end{abstract}

Key Words: Lawsuit, Liability, Litigation, Medicolegal experience

\section{La responsabilité professionnelle des chirurgiens plasticiens au Canada}

RÉSUMÉ : On a passé en revue l'expérience médico-légale des chirurgiens plasticiens du Canada, entre 1980 et 1995 . Au cours des six années les plus récentes (1990 à 1995), 331 recours légaux ont été réglés et ces dossiers ont été analysés par le département de la formation de l'Association canadienne de protection médicale. Les poursuites judiciaires avaient pour la plupart trait à la chirurgie mammaire (26 \%); mais les chirurgies du visage $(21 \%)$ et de la main $(19 \%)$ ont aussi contribué à ce nombre. L'examen des dossiers a révélé que les cas ont souvent abouti à un non-lieu $(64 \%)$ ou ont été gagnés si un procès avait lieu $(9 \%)$; toutefois, $23 \%$ ont nécessité un règlement hors cour au nom du chirurgien défendeur, alors que $4 \%$ ont été perdus lors des procès. Les dommages les plus imposants versés avaient trait à la chirurgie de la main. Le coût élevé de la défense des chirurgiens plasticiens est le reflet de la fréquence des poursuites plutôt que de la gravité des cas ayant donné lieu à un recours légal.

\begin{abstract}
$\mathrm{A}$ $\mathrm{t}$ the Canadian Medical Protective Association (CMPA), data are continually collected to record the source and the reason for requests for help from members. This repository of information enables analysts at the Association to gather retrospective data for a specific professional category (specialty), such as plastic surgery, and thereby reveal a cumulative experience over a specified time interval.

Civil litigation against plastic surgeons and the outcome of those actions can be examined. Such a review can provide insight into factors that may give rise to litigation or complaint, and possibly lend assistance in the continual efforts of
\end{abstract}

Correspondence and reprints: Dr W Bryan Callaghan, 139 Greenbank Road \#200, Nepean, Ontario K2H 9A5. Telephone 613-721-6463,

fax 613-721-9899, e-mail calla.wb@sympatico.ca risk management. The pattern of legal outcomes from the resolution of these actions enables surgeons to observe how standards of care are measured in a court of law.

These data are not intended to sound the alarm bell or serve notice of concern. Rather, this information may provide further resources to the specialty of plastic surgery to facilitate constructive reappraisal and continuing quality assurance.

\section{SCOPE OF THE REVIEW}

All recorded contacts with the CMPA by plastic surgeons from January 1, 1980 to December 31, 1995 were reviewed. These represented 2635 case types arising from 1857 clinical incidents. (One adverse clinical incident may give rise to many different case types recorded at the CMPA, eg, call for 
TABLE 1: Outcomes of legal actions against medical doctors that were closed from 1990 to 1995

\begin{tabular}{lcc}
\hline & \multicolumn{2}{c}{$\begin{array}{c}\text { Percentage of legal actions } \\
\text { resulting in outcome }\end{array}$} \\
Outcome & $\begin{array}{c}\text { Plastic surgery } \\
(\mathbf{n}=\mathbf{3 3 1})\end{array}$ & $\begin{array}{c}\text { CMPA total } \\
(\mathbf{n}=\mathbf{5 4 0 7})\end{array}$ \\
\hline $\begin{array}{l}\text { Dismissal } \\
\text { Judgement for medical } \\
\text { doctor }\end{array}$ & 64 & 64 \\
$\begin{array}{l}\text { Settlement } \\
\text { Judgement against medical } \\
\text { doctor }\end{array}$ & 9 & 6 \\
\hline
\end{tabular}

CMPA Canadian Medical Protective Association

advice, college complaint, or threat or initiation of lawsuit.) During this 15-year interval, 917 legal actions were brought against plastic surgeons. By 1995, 61\% (562) had been closed and the outcomes recorded in the CMPA files, permitting an opportunity to examine a significant volume of the medico-legal experience for this presentation.

The most recently resolved legal actions should provide the most recent reflection of the medico-legal climate in Canada. Therefore, closed legal cases from 1990 to 1995 (331 lawsuits) were examined in greater detail and are reported here.

\section{PATTERN OF PLASTIC SURGERY COMPLAINTS}

From the 15-year total, including all contacts from plastic surgeons, 2635 calls representing all case types were recorded. Seventeen per cent were threats of lawsuit, $35 \%$ were lawsuits, $12 \%$ were college complaints and $35 \%$ were requests for advice.

Compared with the general membership of the CMPA over an identical time period, requests for advice represented almost $70 \%$ of case types, while lawsuits provided only $10 \%$ of calls from the general membership. From 1990 to 1995, two of three plastic surgeons called the CMPA at least once, while the rate of contact for the total membership was one in five.

\section{LEGAL ACTIONS}

The number of new legal actions brought against plastic surgeons each year has been increasing steadily. In 1980, 40 lawsuits were opened, and in 1988, new legal actions numbered 65. In 1995, 85 legal actions were brought against plastic surgeons in Canada, the highest annual total ever recorded for the specialty.

In 1995, the risk of lawsuit was one in four for plastic surgeons and one in 40 for the general membership.

From 1990 to 1995, the most recent six-year period for which data was available, a plastic surgeon was the sole physician defendant in $95 \%$ of 331 closed legal actions. Family physicians were named as codefendants in $1 \%$ of cases and house staff physicians in $1 \%$.
TABLE 2: Duration until closure for legal actions against medical doctors from 1990 to 1995

\begin{tabular}{lcc}
\hline & \multicolumn{2}{c}{ Months until outcome } \\
Outcome & $\begin{array}{c}\text { Plastic surgery } \\
(\mathbf{n}=\mathbf{3 3 1})\end{array}$ & $\begin{array}{c}\text { CMPA total } \\
(\mathbf{n}=\mathbf{5 4 0 7})\end{array}$ \\
\hline $\begin{array}{l}\text { Dismissal } \\
\begin{array}{l}\text { Judgement for medical } \\
\text { doctor }\end{array}\end{array}$ & 38 & 36 \\
$\begin{array}{l}\text { Settlement } \\
\text { Judgement against } \\
\text { medical doctor }\end{array}$ & 54 & 55 \\
\hline
\end{tabular}

CMPA Canadian Medical Protective Association

Reconstructive procedures accounted for $56 \%$ of litigations and cosmetic procedures for $44 \%$.

When anatomical location of the surgery was correlated with the incidence of legal actions, $26 \%$ of legal actions were for breast, $21 \%$ for face, $19 \%$ for hand, $9 \%$ for body contour, $8 \%$ for nose, $7 \%$ for cutaneous, $6 \%$ for lower extremity, $3 \%$ for eyelids and $1 \%$ for external genital.

When sex and age of the plaintiff were examined for plastic surgery cases, $71 \%$ of claims were filed by females and $29 \%$ by males. Mean age of the plaintiff was 37 years. The plaintiffs in general CMPA cases (5407 legal actions) during the same period (1990 to 1995) had a female:male ratio of 14:11 and a mean age of 36 years.

\section{OUTCOMES OF LEGAL ACTIONS}

Four outcome categories were recorded for 331 plastic surgery legal actions closed from 1990 through 1995 (Table 1). Duration of the legal action was compared with the outcome, and average duration until closure was calculated in months for each of the outcome categories. This was compared with the overall collective CMPA cases on behalf of all members (5407 lawsuits) during the same time period (Table 2).

Disbursements for plastic surgery cases that were dismissed averaged in excess of $\$ 10,000$. This figure represents legal costs, costs of expert opinion and the minor administrative costs of managing the file. For cases that were settled, average disbursements (damages plus legal costs and expertise) remained below $\$ 80,000$ for plastic surgery legal actions. Of the 15 most costly settlements among the 331 recent closed cases, seven involved elective hand surgery.

\section{SELECT CASE CATEGORIES OF INTEREST}

Reduction mammaplasty accounted for 40 cases from 1990 to 1995 . Of these, $72 \%$ had a favourable medico-legal outcome (dismissed or won), while $28 \%$ ended unfavourably (settled or lost at trial). These will be examined in further detail in a subsequent presentation.

Thirty-five cases arose from elective hand surgery, of which eight were carpal tunnel releases. Forty per cent of these hand lawsuits were settled, unable to garner expert support for the standard of care. The quantum of damages was 


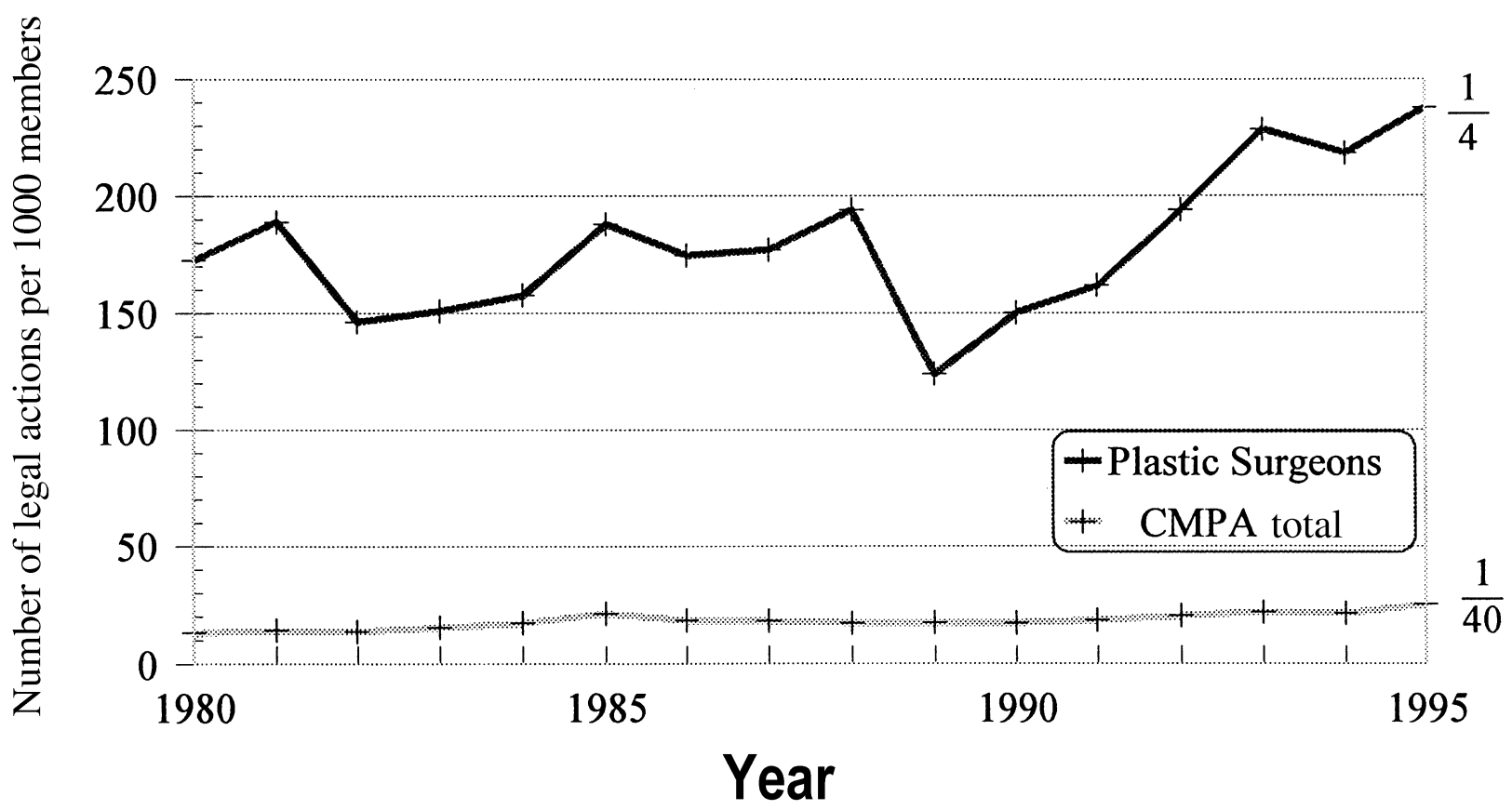

Figure 1) Risk of legal action for plastic surgeons versus general Canadian Medical Protective Association (CMPA) membership

comparatively large because it included future loss of income for generally young patients.

Cosmetic facial surgery (excluding nose and eyelids) accounted for 41 of 331 legal actions. The reason for claim in almost half (44\%) was unsatisfactory scars. The scars arose from face lift surgery in 11 cases and from dermabrasion/chemabrasion in six. Two cases involved facial nerve injuries.

In this same six-year sample, augmentation mammaplasty contributed to 28 of 331 closed cases. The reason for claim in $50 \%$ was asymmetry or unsatisfactory breast shape. Dismissals were achieved in 18 (64\%); however six (21\%) were settled and two others lost at trial. Favourable trial decisions were won in two augmentation cases.

\section{CANADIAN PLASTIC SURGEONS AND PROFESSIONAL LIABILITY}

Within the membership of the CMPA, plastic surgeons comprise less than $1 \%$ of the total. While the CMPA exists as a mutual medical defence organization, the costs of defending its members are monitored and attributed to each respective specialty. Therefore, the cost of defending plastic surgeons is spread over the comparatively small number within the specialty. There is less buffered effect than that which benefits larger specialties.

While the injuries sustained, and consequently the damages awarded, remain moderate and, for plastic surgery, well out of the catastrophic range, there is nonetheless an issue of frequency. Plastic surgeons seek assistance from the CMPA more frequently than all other specialties (Figure 1). One in four are involved in legal action - more than other specialties in the upper fee categories such as neurosurgery, obstetrics or orthopedics.

The specialty will benefit from risk management initiatives directed at controlling the frequency with which plastic surgeons are challenged on matters of professional liability.

ACKNOWLEDGEMENTS: The author acknowledges the assistance of Dr William Beilby, Director of the Education Department, CMPA, in the preparation of materials for this study. 